SECOND CHANCES 
CRITICAL GLOBAL HEALTH

EVIDENCE, EFFICACY, ETHNOGRAPHY

Edited by Vincanne Adams and João Biehl 


\title{
SECOND CHANCES
}

Susan Reynolds Whyte, Editor

\author{
SURVIVING AIDS \\ I N U A N D A
}

DUKE UNIVERSITY PRESS Durham and London 2014 
(C) 2014 Duke University Press

All rights reserved

Printed in the United States of America on acid-free paper $\infty$

Designed by Natalie F. Smith

Typeset in Minion Pro by Copperline

Library of Congress Cataloging-in-Publication Data

Second chances : surviving aids in Uganda / Susan Reynolds Whyte, ed.

pages $\mathrm{cm}-$ (Critical global health : evidence, efficacy, ethnography)

Includes bibliographical references and index.

ISBN 978-0-8223-5795-7 (cloth : alk. paper)

ISBN 978-o-8223-5808-4 (pbk. : alk. paper)

1. AIDS (Disease)-Patients-Uganda. 2. HIV-positive persons-Uganda.

I. Whyte, Susan Reynolds. II. Series: Critical global health.

RC606.54S43 2014

362.19697'920096761-dc23

2014012919]

Cover photo: Sign for the Antiretroviral Therapy Clinic and the Outpatient Department (O.P.D.) at Kagando Hospital, Kasese District, Uganda

(21 January 2013). Photograph by Susan Reynolds Whyte

Duke University Press gratefully acknowledges the support of the Danish Ministry of Foreign Affairs, which provided funds toward the publication of this book. 